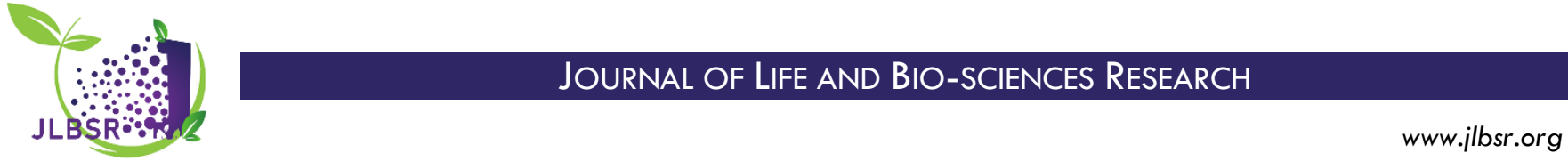

\title{
Morphological, Histological Changes and Acetyl Cholinesterase Activity in Chicken Embryos After Exposure to Abamectin Insecticide
}

\author{
Banan Abdulmohsin Taha and Rabeea Hazim Mohammed* \\ Department of Biology, College of Education for Pure Science, University of Mosul, Mosul, Iraq \\ (Banan.a.m.t.99@gmail.com)(dr.rabeeahm@uomosul.edu.iq) \\ *Correspondence: dr.rabeeahm@uomosul.edu.iq
}

\begin{abstract}
Abamectin is a bio-insecticide, derived from the soil bacteria Streptomyces avermitilis. This insecticide is used in public health and agriculture to protect crops. Major adverse impacts of Abamectin are neurological symptoms acting on the peripheral nervous system. The aim of the current study is to reveal the toxic effects of Abamectin on chick embryo Ross 308 including morphological and histological changes and acetyl cholinesterase activity. 120 fresh fertilized eggs were divided into 6 groups; two of them were used as control. After 2 days of incubation, the eggs were injected with $100 \mu \mathrm{L}$ of Abamectin solution (diluted at concentrations 360, 540, 900 and $1800 \mathrm{ppm}$ ) into the yolk sac. The Results showed that the mortality increased significantly in chicks treated with Abamectin, but had a lower weight in comparison to the control groups. Treated chicks started hatching at day 22 but were physically weak with drooping limbs, paralysis and then died after 24 hours of hatching. Some chicks did not normally hatch and needed assistance. They characterized by limb defects, failure retraction of yolk sac with bleeding. Histological examination of the liver showed hepatic cell degeneration, congestion in the central vein, infiltration of inflammatory cells and hepatocytes necrosis. Furthermore, the Acetyl cholinesterase enzyme analysis showed a significant decrease in the enzyme activity which leads to inhibition the activity of the body systems. It is concluded that low and high concentration of Abamectin has adverse impacts on chick embryo by changing some of morphological, histological characteristics and acetyl cholinesterase activity.
\end{abstract}

Keywords: Abamectin, Acetyl Cholinesterase, Morphological, Chick Embryo Ross308

Received: September $6^{\text {th }}, 2021 /$ Accepted: October $28^{\text {th }}, 2021 /$ Online: November $1^{\text {st }}, 2021$

\section{INTRODUCTION}

Abamectin (AM) is a bio insecticide, used in public health and agriculture to protect citrus, pears, apples, fruits, potatoes, tree nuts and different of other vegetables (Akashe et al., 2018). AM derives of avermectin from the soil bacteria Streptomyces avermitilis. It belongs to a general class of closely related macrocyclic lactones and consists of two components including major avermectin B1a (CAS No. 65195-55-3) and avermectin B1b (CAS No. 65195-56-4) which in turn consists of about $80 \%$ and $20 \%$ respectively. Both B1a and B1b possess a structure of 16-membered ring (figure 1) (Takahashi et al., 2002; Jayakumar, 2009).

The toxicity effect of Abamectin occurs as a result of the interaction between these of two active components (Yoon et al., 2004; Campbell, 2012). Major adverse impacts of Abamectin are neurological symptoms acting on neuron receptor gamma amino butyric acid (GABA) in the peripheral nervous system (Raftery and Volz, 2015; Novelli, 2016). These effects are mydriasis tremor/convulsion through the interaction between GABA-ergic and hyperpolarization of muscle cells/nerve.

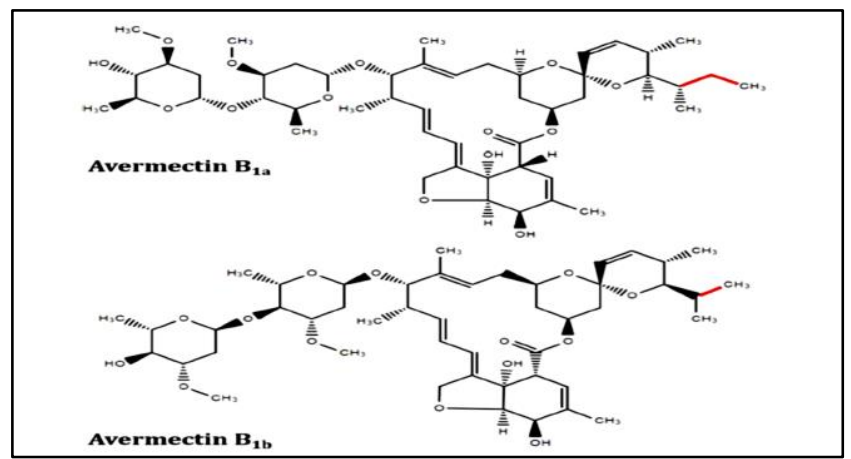

Figure1: showing chemical structure of Abamectin: Abamectin as structure consists of natural avermectins B1a and B1b. B1a compounds of ethyl group while B1b has a methyl group attached in the ring (Teralı et al. 2018).

Neither genotoxicity nor developmental neurotoxicity, reproductive toxicity and carcinogenicity were observed. Pesticide affects neuron transmitter Acetylcholine by 
inhibition cholinesterase enzyme activity and then leading to accumulation on neuromuscular synaptic and occurrence neurotoxicity (Wilson et al., 2005; Bjorling- Poulsen et al., 2008). Acetyl cholinesterase inhibition is a bio indicator for exposure toxic pesticides (Abass, 2014; Fossati et al., 2015), which leads to physiological weakness (Sardar et al., 2020) neuronal degeneration (Kennedy et al., 2014; Thiripurasundari et al., 2014) and changing behaviour in Oreochromis mossambicus (Kushwaha et al., 2020). The exposure to insecticides is associated with inhibition of acetyl cholineesterase in the central nerve system especially in the brain (Wilson et al., 2005) due to the lipophilic of Abamectin properties (Khanna et al., 2002; Novelli et al., 2012). Only one study refers to the decrease Acetyl cholinesterase (also known as Ach E) activity in tissue brain to $48-96 \%$ in 26 species wild birds, among them Gallus gallus domestics (Bang et al., 2019). The chicken meat is a source of protein for human-being in many different countries. Poultry feed may contain residues of pesticides, which accumulated in food chain down to terminal consumer (Koc and Karakus, 2011; Salar-Amoli and Ali-Esfahani, 2015). The chick embryo is an excellent model for toxicological research (Kotwani, 1998). Therefore, the current study aimed to reveal morphological, Histological changes and Ach E activity after exposure to Abamectin insecticide in chick embryo.

\section{MATERIALS AND METHODS}

The current study used the commercial biocide Abamectin $1.8 \%$ EC (Emulsifiable Concentrate), product from King Quesson Industry Co., Ltd in China. The stock solution of insecticides was diluted to prepare four concentrations of the insecticide 360, 540, 900, and 1800 ppm (Part per million).

\section{A. Experimental Design}

120 Fresh fertilized eggs of chick broiler Ross 308 were purchased from Rison Company in Erbil city. Eggs were weighted, 65-68 gram and then cleaned by cotton and Ethanol $70 \%$ to remove any contamination on the egg shell. The eggs were then divided into six groups, 20 eggs for each including the control groups negative (normal) and positive were injected with distilled water. After that, the eggs were incubated at temperature $37 \pm 0.5^{\circ} \mathrm{C}$ and relative humidity 70 $75 \%$. After two days of incubation, the eggs were injected with single dose $100 \mu \mathrm{L}$ according to (Chaudhary, et al., 2017) for each concentration 360,540 , 900, and $1800 \mathrm{ppm}$, into the yolk sac by using $0.3 \mathrm{~mL}$ syringes with fine needle. Injected eggs were then closed by adhesive tape to avoid the contamination.

\section{B. Histological Study of the Liver}

The liver of chicks was quickly removed and fixed in formaldehyde solution $10 \%$, and then washed in different concentrations of the ethanol. Tissues were dehydrated and then embedded in paraffin wax and later sectioning using the rotary microtome Leitz 1512 MH340/German. Sections were cut at $6 \mu \mathrm{m}$ in thickness then staining with Haematoxylin and
Eosin (H\&E). Tissues of the liver were photographed by microscope digital camera SCMOS- 05000KPA.

\section{Preparation of Samples and Enzyme Analysis}

After 21 embryonic days of incubation at about a stage of 45 according to (Hamburger and Hamilton, 1951) brains of the treated chick embryo were removed by a scalpel and then stored at $-20^{\circ} \mathrm{C}$. Brains of chick embryo were homogenized by crushing mortar and mixed with $3 \mathrm{ml}$ distilled water and $3 \mathrm{ml}$ buffer solution. According to (Alias and Mohammad, 2005; Mohammad, 2007), buffer solution was prepared on $\mathrm{pH} 8.1$ and consisted of $0.19 \mathrm{~g}$ Sodium Chloride, $4.38 \mathrm{~g}$ Sodium Barbital and 0.02g potassium di-hydrogen phosphate from Sigma Aldrich were dissolved in $125 \mathrm{ml}$ distill water. By using $\mathrm{pH}$ meter (PHS-3BW) was measured changing $\mathrm{pH}$ 1 of the homogenate brain solution (HBS), then add $0.2 \mathrm{ml}$ acetylcholine iodide $7.1 \%$ (Substrate) to the HBS for measured the $\mathrm{pH} 2$. While, the $\mathrm{pH}$ of blank solution was measured by adding $3 \mathrm{ml}$ distill water, $3 \mathrm{ml}$ buffer solution with $0.2 \mathrm{ml}$ substrate $7.1 \%$. The changing of $\mathrm{pH}(\Delta \mathrm{pH})$ was calculated as follows: $\Delta \mathrm{pH}=(\mathrm{pH} 1-\mathrm{pH} 2)-\mathrm{pH}$ blank.

\section{Statistical Analysis of Data}

The data of weights of chick embryos and Acetylcholinesterase analysis was calculated by Statistical Analysis System (SAS) Completely Randomized Design. One way ANOVA, Duncan Multiple Range. The values showed significant decrease $\mathrm{p}<0.01$ and $\mathrm{p} \leq 0.05$.

\section{RESULTS}

The current study focused on chick age 21 day of incubation to investigate the morphological and physiological effects of Abamectin insecticide. As mentioned above, four concentrations of this insecticide (360, 540, 900 and 1800 ppm) were used by injection the yolk sac with $100 \mu$ of the insecticide. On day 21 of incubation, chicks of control groups (negative and positive) were normally hatched and physically active (figure $2 \mathrm{~A}$ ). On the other hand, chicks of treatment groups at concentrations $360,540 \mathrm{ppm} / \mathrm{egg}$ were delayed in hatching to day $22^{\text {ed }}$ of incubation. They were physically weak, panting with droopy wings, weakness of hind-limbs and cannot normally walk. Chicks also showed complete paralysis, coma and they died after 24 hours of hatching (figure 2B and C). Eggs treated with 900 and 1800 ppm/egg did not normally hatch and they needed assistance. Treatment with concentrations $900 \mathrm{ppm} / \mathrm{egg}$ led to failure to retract the yolk sac, adjoining legs and arched toes (figure 2D). Similarly, Abamectin at concentrations 1800 ppm caused splayed legs with curved toes, delayed yolk sac retraction with hemorrhage (figure 2E). 

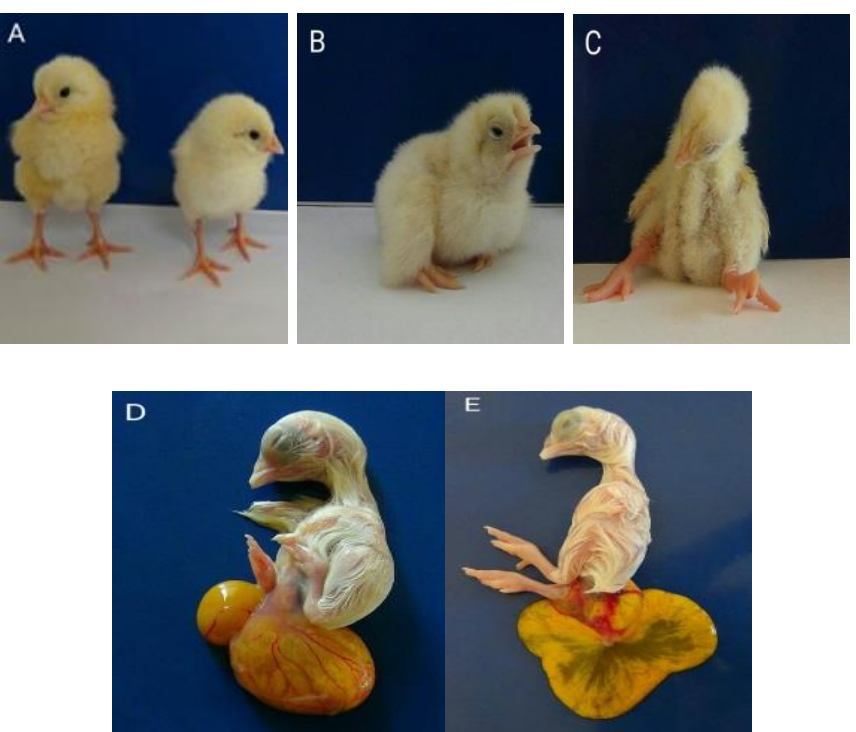

Figure 2: (A) represents control group. B, C, D and E chick treated with 360, 450, 900 and $1800 \mathrm{ppm}$ of Abamectin respectively.

As it is shown in table 1, the current study also showed a significant increase in the mortality in chicks treated with Abamectin in comparison to the control groups. The mortality was $65 \%$ in embryos treated with $360 \mathrm{ppm}$, while the higher percentage was $90 \%$ in embryos treated with $1800 \mathrm{ppm}$ compared to negative $(5 \%)$ and positive $(10 \%)$ control groups. Moreover, the control average weight was $(48 \mathrm{~g}$ and $46 \mathrm{~g}$ ) for negative and positive control groups respectively, while injected the chick embryos with Abamectin had a lower weight compared to the controls (figure 3).

Table 1: Showing mortality percentage and weights of embryo Ross 308 in experimental groups.

\begin{tabular}{|c|l|c|c|c|c|}
\hline $\begin{array}{c}\text { Experi } \\
\text { ment } \\
\text { group }\end{array}$ & $\begin{array}{l}\text { Doses/ } \\
\text { egg } \\
\text { A }\end{array}$ & $\begin{array}{c}\text { No. of } \\
\text { egg } \\
\text { treatment }\end{array}$ & $\begin{array}{c}\text { No. of } \\
\text { dead } \\
\text { embryo }\end{array}$ & $\begin{array}{c}\text { Mortality } \\
\%\end{array}$ & $\begin{array}{c}\text { Weight of } \\
\text { embryo (g) } \\
\text { Mean } \pm \mathrm{SE}^{\text {(a) }}\end{array}$ \\
\hline $\begin{array}{c}\text { Group } \\
\text { B }\end{array}$ & 100 & 20 & 1 & 5 & $48.0 \pm 1.20^{* *}$ \\
\hline $\begin{array}{c}\text { Group } \\
\text { C }\end{array}$ & 360 & 20 & 13 & 65 & $38.0 \pm 1.15^{*}$ \\
\hline $\begin{array}{c}\text { Group } \\
\text { D }\end{array}$ & 540 & 20 & 15 & 75 & $34.6 \pm 1.76^{*}$ \\
\hline $\begin{array}{c}\text { Group } \\
\text { E }\end{array}$ & 900 & 20 & 17 & 85 & $32.0 \pm 2.64^{*}$ \\
\hline $\begin{array}{c}\text { Group } \\
\text { F }\end{array}$ & 1800 & 20 & 18 & 90 & $29.3 \pm 3.17^{*}$ \\
\hline
\end{tabular}

(a) The Values weight of embryo are expressed as Mean \pm SE (standard Error) were showed significant decrease on $* * p<0.01, * p \leq 0.05$

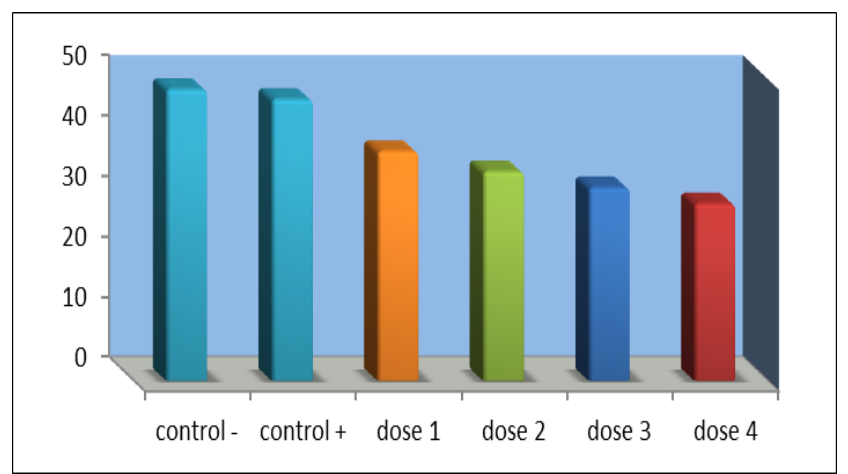

Figure 3: Demonstrates a significant decrease in the weights of treated chick embryo Ross 308 compared to the control groups.

Microscopically, sections in the liver of control chick ED 21 showed normal architecture in the liver cells, normal sinusoids and normal central vein (figure $4 \mathrm{~A}$ and B). Briefly, histological sections in the liver of chick embryos treated with 900 and $1800 \mathrm{ppm}$ (figure 4C,Cc and D,Dd) of Abamectin on ED 21 observe dilatation and congestion in the central vein and sinusoidal space necrotic cells. In addition, there was hepatic cells degeneration as well as infiltration of inflammatory cells.

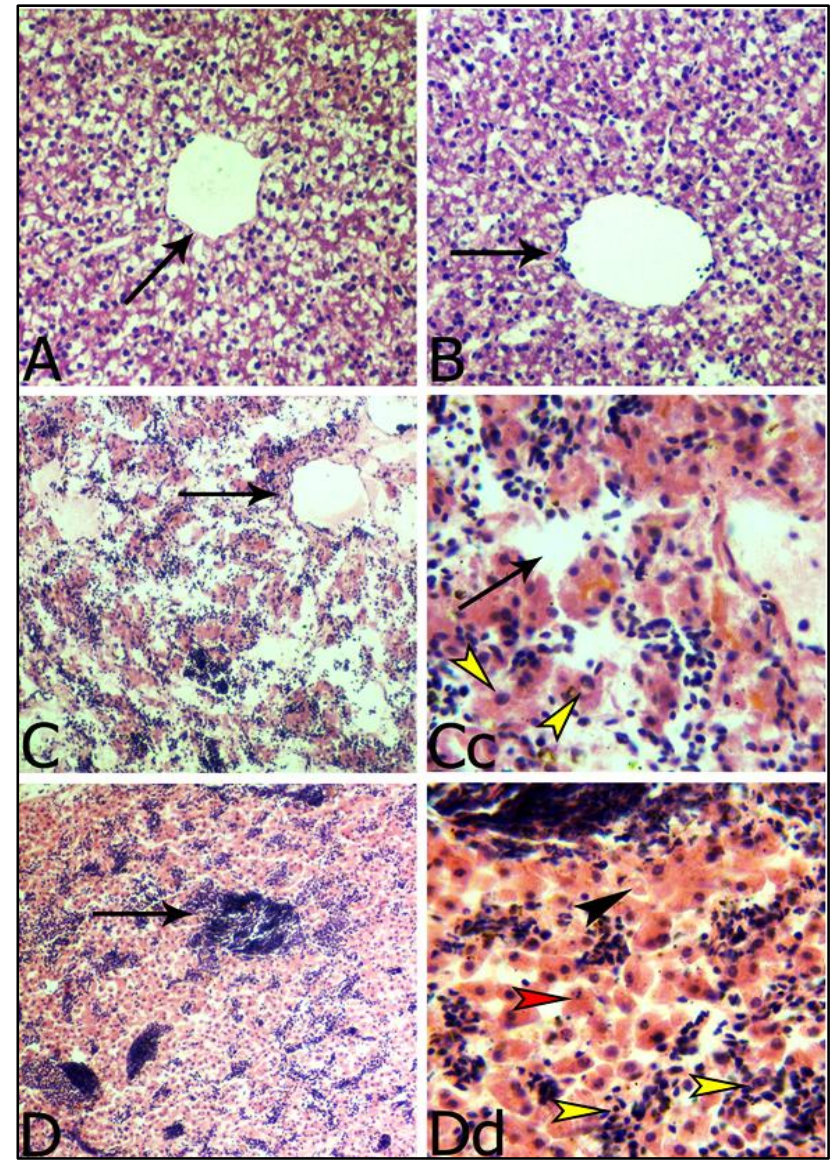

Figure 4: showing histological sections in the liver of chick embryos on 2122 day of incubation. (A and B) sections of control groups B, injected with distilled water. The control groups show normal structure of the hepatocytes around the central vein (black arrow). ( $\mathrm{C}$ and $\mathrm{Cc}$ ) sections magnification 
(10X and 40X respectively) in the liver treated with $900 \mathrm{ppm}$ of Abamectin on ED 21 show dilatation in sinusoids with bleeding (Black arrow) and vacuolization (yellow head arrow). (D and Dd) sections magnification (10X and $40 \mathrm{X}$ respectively) in the liver treated with $1800 \mathrm{ppm}$ of Abamectin on ED 21 observe congestion of central vein with infiltration of inflammatory cells (black arrow). It can be also seen dilatation in blood sinusoid with necrosis (red head arrow) vacuolization (black head arrow) and infiltration of inflammatory cells (yellow head arrow). (Section stained by Haematoxylin and Eosin).

The current study also revealed the activity of Acetyl cholinesterase (Ach E) in chick embryo after treatment with Abamectin insecticide. As shown in table 2, the Ach E analysis decreased significantly in enzyme activity at percentage $73 \%, 87 \%, 90,97 \%$ respectively due to 360,540 , 900 and 1800 ppm of insecticide respectively.

Table 2: showing changing of values $\mathrm{pH}(\Delta \mathrm{pH})$ and inhibition percentage of Ach $\mathrm{E}$ activity in chick broiler Ross 308 .

\begin{tabular}{|c|c|c|c|}
\hline $\begin{array}{c}\text { Experimental } \\
\text { groups }\end{array}$ & Doses/ppm & $\begin{array}{c}\Delta \mathrm{pH} \\
\text { Mean } \pm \mathrm{SE}\end{array}$ & Inhibition\% ${ }^{\text {(a) }}$ \\
\hline Croup A & - & $0.86 \pm 0.01$ & 0 \\
\hline Croup B & 100 & $0.86 \pm 0.01$ & 0 \\
\hline Croup C & 360 & $0.23 \pm 0.21$ & 73 \\
\hline Croup D & 540 & $0.11 \pm 0.90$ & 87 \\
\hline Croup E & 900 & $0.085 \pm 0.55$ & 90 \\
\hline Croup F & 1800 & $0.025 \pm 0.15$ & 97 \\
\hline
\end{tabular}

(a) Inhibition $\%=\Delta \mathrm{pH}$ control $-\Delta \mathrm{pH}$ treated $/ \Delta \mathrm{pH}$ control $* 100$

The values of $\Delta \mathrm{pH}$ expressed significantly decreased $\mathrm{p} \leq 0.05$.

\section{DISCUSSION}

Pesticides are chemical or biological compounds used in agriculture to protect crops from the pest and, in veterinary, to prevent the spread of diseases carrying parasites insect (Gul et al., 2017; Akashe et al., 2018) Abamectin $1.8 \%$ EC is a bio insecticide available in commercial markets with different names. Therefore, the current work was carried out to investigate the effect of this insecticide on chicks at $21 \mathrm{st}$ day of incubation. Chick embryos are a good model for studding the toxicity of chemical, because they are easy to manipulate and their development is short and may homolog genomic structure with higher vertebrates. These reasons made the chick as a perfect model for studying changes morphogenetic (Stern, 2018) and neurobehavioral (AbdulGani et al., 2012).

The liver is an effective organ in removing the toxic effect of many substances and particles that enter the body, as well as removing vital detoxification and xenobiotic of organs (Hernandez et al., 2013). Exposure to insecticides affects the liver function and activities enzyme Alanine aminotransferase (ALT), Aspartate amino -transferase (AST) which leads to liver tissue damage (McGill, 2016). A high level of ALT and AST enzyme in serum or plasma causes hepatotoxicity and leakage of lysosome enzyme (Chaudhary et al., 2003). The elevation in the level of ALT, AST is associated with histopathological lesions like degeneration of hepatic cell, enlargement dilation of sinusoids and vacuolar degeneration (Ksheerasagar et al., 2011). Many of studies revealed a significant increase in the ALT and AST enzymes after exposure to insecticides (Farag et al., 2016; Kushwaha et al., 2020). Moreover, exposure to insecticides induces oxidative stress and production of reactive oxygen species (ROS) which in turn increases the free radical and occurrence damage of macromolecules such as proteins, lipids and DNA damage (Agrawal and Sharma, 2010; Sharma and Sangha, 2014). The exposure to insecticides is associated with histopathological alteration in liver tissues such as necrotic changes and damaged of hepatocytes (Ahmed et al., 2020; Basal et al., 2020).

Abamectin plays on Ca-Mg ATPase enzyme and decreases of intracellular Calcium level which in turn leads to inhibition of Ach E activity and accumulation Acetylcholine (Bradberry et al., 2005; Lotti, 2010). Furthermore, Abamectin affects GABA receptor by activation of gated chloride channels, which allows chloride ions flows to intracellular then caused hypopolarization of muscles (Xu et al., 2017; Srivastava et al., 2020). Basically, the inactivation of Ach E leads to twitching of muscles and causes tetanus and paralysis of muscles (Singh et al., 2004). The current study revealed that treatment of chick embryos with Abamectin at does 360 and/or 540 ppm causes droopy wings as well as splayed legs, which led to paralysis or weakness of baby chicks. This finding is in agreement with Sardar and colleagues who showed that Abamectin at dose $5,10 \mathrm{mg} / \mathrm{kg}$ causes muscle weakness and also impaired movement (Sardar et al., 2020). Exposure to Abamectin insecticide results in the decrease of swimming speeds in fish after 48 hours of treatment (Kushwaha et al., 2020). Moreover, insecticide affects embryos in different ways and can cause teratogenicity in chick embryos Rhode Island Red, such as unsteady gait, crooked legs and twisted phalanges (Uggini et al., 2012). Other studies investigated that insecticides probably delay the development, failure of retraction yolk sac with bleeding and hematomas (Bhaskar et al., 2012; Hussein and Singh, 2016). These results are in agreement with findings of the current work during treatment with Abamectin at dose 900 and 1800 ppm. From a review of previous literature, it still unknown the effect of bio insecticide on Ach E activity in the brain of chick embryo during the development. The current study, therefore, investigated that Abamectin causes significant decrease in Acetyl cholinesterase activity at 74- $97 \%$ in the brain of chick embryo. Abass and Salih (2016) showed low activity of Ach E in rabbit's brain to $92 \%$ when they treated with Malathion insecticide.

Alhifi (2018) observed a decrease in the percentage inhibition of Ach E to $40.6 \%$ and $69 \%$ in brain tissue of chick embryo Gallus gallus treated with mixed insecticide (dimethoate $30 \%$ + methidathion 40\%) at dose 4, 8 ppm, respectively. Pesticides interfere with physiological chemical processes and leading to morphological changes (Teralı et al., 2018; Uggini et al., 2012; Legradi et al., 2018; Hernandez et al., 2020). 


\section{V.CONCLUSION}

To conclude, that exposure to bio insecticide Abamectin has different effects on chicks. Treated chicks with this insecticide were physically weak with paralysis. Abamectin also inhibited the activity of acetyl cholinesterase, which gave bio indicator for pesticide poisoning. Suppressing of Ach E affected functions systems and inhibited the growth of body organs as well as abnormal change in behavior and physiological activity. Thus, Abamectin insecticide possesses physiological and morphological effects on the avian and probably on other vertebrates.

\section{ACKNOWLEDGEMENT}

This work was supported by faculty of Veterinary Medicine/ Department of physiology, Biochemistry and pharmacology, University of Mosul, Iraq.

\section{REFERENCES}

Abass, K.S., Salih, K.A. (2016). Cholinesterase effect of pesticides in rabbit embryos and their potential for use in hazard assessment. Journal of Veterinary Science and Technology, 7:6.

Abass, K.S. (2014). Experimental measurement for the effect of dilution procedure in blood esterase as animals biomarker for exposure to OP Compounds. BioMed Research International, 451982.

Abdul-Gani, S., Yanai, J., Abdul-Ghani, R., Pinkas, A., Abdeen, Z. (2012). The teratogenicity and behavioral teratogenicity of di(2-ethylhexyl) phthalate (DEHP) and di-butyl phthalate (DBP) in a chick model. Journal of Neurotoxicology and Teratology, 34(1), 56-62.

Agrawal, A., Sharma, B. (2010). Pesticides induced oxidative stress in mammalian systems. International Journal of Biological and Medical Research, 1(3), 90-104.

Ahmed, A.E., Al-Kahtani, M.A., Khalil, A.M., Alshehri, A.S., Elghoneimy, A.A., Elbehairi, S.E.I., Alfaifi, M.Y., Shati, A.A., Morsy, K.S., Alshehri, M.A. (2020). Co-administration of vitamin E and selenium in vivo and in vitro ameliorates the toxic effects caused by ivermectin and doramectin. Veterinarni Medicina, 65(2), 71-83.

Akashe, M.M., Pawade, U.U., Nikam, A.V. (2018). Classification of pesticides, A review. International Journal of Research in Ayurveda and Pharmacy, 9(4), 144-150.

Alhifi, M.A. (2018). Effect of pesticides mixture of dimethoate and methidathion on acetyl cholinesterase during embryo development using chick embryo model. Egyptian Academic Journal of Biological Sciences, F. Toxicology and Pest Control, 3(1), 19-26.

Alias, A.S., Mohammad, F.K. (2005). Electrometric measurement of plasma and tissue cholinesterase activities of four wild bird in Iraq. J Boil Res, 4, 197-202.

Bang, J.H., Ku, H.O., Kang, H.G., Kim, H., Kim, S., Pargk, S.W., Kim, Y.S., Jang, I.L., Bae, Y.C., Woo, G.H., Yi, H. (2019). Acetyl cholinesterase activity in the brain of wild birds in Korea-2014 to 2016. Journal of Veterinary Science, 20(2), e9.

Basal, W.T., Ahmed, A.R.T., Mahmoud, A.A., Omar, A.R. (2020). Lufenuron induces reproductive toxicity and genotoxic effects in pregnant albino rats and their fetuses. Scientific Reports, 10(1), 1-24.

Bhaskar, N., Shahani, L., Taparia, N., Bhatnagar, P. (2012). Effect of deltamethrin containing formulation on developing chick embryo: morphological and skeletal changes. International Journal of Toxicological And Pharmacological Research, 13, 4(4), 81-87.

Bjorling-Puolsen, M., Anderson, H.R., Grandjean, P. (2008). Potential developmental neurotoxicity of pesticides used ii Europe. Environmental Health 2008, 7, 50.

Bradberry, S.M., Cage, S.A., Proudfoot, A.T., Vale, J.A. (2005). Poisoning due to pyrethroids. Toxicological Reviews, 24(2).

Campbell, W.C. (2012). Ivermectin and Abamectin, Springer Sciences and Business Media: Berlin/ Heidelberg, Germany.
Chaudhary, S., Ansari, M. S., Abbas, M. N., Kausar, S., Iqbal, R., Saleem, R., and Sabir, J. I. S. (2017). Toxic effects of chlorpyrifos on $12^{\text {th }}$ day desi chick embryo (Gallus gallus domesticus). Nucleus, 54(2), 136140 .

Chaudhary N., Sharma, M., Verma, P., Joshi, S.C. (2003) Hepato and nephrotoxicity in rat exposed to endosulfan. Journal of Environmental Biology. 24(3), 305-308.

Farag, A.A., Kotb, G.A., Hamza, A.H., Mohmoud, R.H., Elhalwagy, M.A. (2016). Sub chronic impact of organophosphorus insecticide triazophos on liver, kidneys and thyroid in albino rats. International Journal of Advanced Research in Biological Sciences, 3(1), 199-208.

Fossati, S.M., Candiani, S., Maragliano, L., Pennuto, M. (2015) Identification and expression of acetyl cholinesterase in Octopus vylgaris arm development and regeneration: a Conserved Role for ACHE? Molecular Neurobiology 52: 45-56.

Gul, S.T., Khan, A., Farooq, M., Niaz, S., Ahmad, M., Khatoon, A., Hassan, M.F. (2017). Effect of sub lethal doses of thiamethoxam (a pesticide) on hemato-biochemical values in cockerels. Pakistan Veterinary Journal, 37(2), 135-138.

Hamburger, V., Hamilton, H.L. (1951). A series of normal stages in the development of the chick embryo. Journal of Morphology.88,49-92.

Hernandez, A.F., Bennekou, S.H., Hart, A., Mohimont, L., Wolterink, G. (2020). Mechanisms underlying disruptive effects of pesticides on the thyroid function. Current Opinion in Toxicology, 19, 34-41.

Hernandez, A.F., Gil, F., Lacasaña, M., Rodríguez-Barranco, M., Tsatsakis, A.M., Requena, M., Parrón, T., Alarcón, R. (2013). Pesticide exposure and genetic variation in xenobiotic-metabolizing enzymes interact to induce biochemical liver damage. Food and Chemical Toxicology, 61, $144-151$.

Hussein, M., Singh, V. (2016). Effect on chick embryos development after exposure to neionicotinoid insecticide imidacloprid. Jourrnal of the Anatomical Society of India, 65(2016), 83-89.

Jayakumar, J. (2009). Bio-efficacy of Streptomyces avermitilis culture filtrates against root knot nematode, Meloidogyne incognita and reniform nematodes, Rotylenchulus reniformis. Karnataka Journal of Agricultural Science, 22, 567-571.

Kennedy, C.J., Tierney, K.B., Mittelstadt, M. (2014). Inhibition of Pglycoprotein in the blood- brain barrier alters avermectin neurotoxicity and swimming performance in rainbow trout. Aquatic Toxicology, 146 ,176-185.

Khanna, R.N., Gupta, G.S., Anannd, M. (2002). Kinetics of distribution of cypermethrin in blood, brain, and spinal cord after a single administration to rabbits. Bulletin of Environmental Contamination and Toxicology, 69, 749-755.

Koc, F., Karakus, E. (2011). Determination of organochlorinated pesticide residues by gas chromatograph- mass spectrometry after elution in a florisil column. Kafka's Universitesi Veteriner FakultesiDergisi, 17(1), 65-70.

Kotwani, A. (1998). Use of chick embryo in screening for teratogenicity. Indian Journal of Physiology and Pharmacology, 42(2), 189-204.

Ksheerasagar, R.L., Hiremath, M.B., Kaliwal, B.B. (2011). Impairment of hepatic biochemical contents and enzymes activities during carbosulfan intoxication in albino mice. International Multidisciplinary Research Journal, 1(3).

Kushwaha, S., Anerao, I., Rajput, S., Bhagriya, P., Roy, H. (2020). Evaluation of abamectin induced hepatotoxicity in Oreochromis mossambicus. Cogent Biology, 6, 1761277.

Legradi, J.B., Paolo, C., Kraak, M.H.S., Van der Geest, H.G., Schymanski, E.L., Williams, A.J., Dingemans, M.M., Massei, R., Brack, W., Cousin, X., Begout, M.L. (2018). An ecotoxicological view on neurotoxicity assessment. Enviromental Sciences Europe, 30(1), 46.

Lotti, M. (2010). Clinical toxicology of anticholinesterase agents in humans. In Hayes' handbook of pesticide toxicology (pp. 1543-1589). Academic Press.

McGill, M.R. (2016). The past and present of serum aminotransferases and the future of liver injury biomarkers. Excli Journal, 15, 817.

Mohammad, F.K. (2007). Review of a particle electrometric method for determination of blood and tissue cholinesterase activities in animals. Vet Scan, 2, 1-12

Novelli, A., Vieira, B.H., Braun, A.S., Mendes, L.B., Daam, M.A., Espindola, E.L.G. (2016). Impact of runoof water from an expermintal agricultural field applied with Vertimes ${ }^{\mathrm{R}} 18 \mathrm{EC}$ (Abamectin) on the 
survival, growth and gill morphology of zebrafish juveniles. Chemosphere, 144, 1408-1414.

Novelli, A., Vieira, B.H., Cordeiro, D., Cappelini, L.T.D., Vieira, E.M., Espindola, E.L.G. (2012). Lethal effects of Abamectin on the aquatic organisms Daphnia similis, Chironomus xanthus and Danio rerio. Chemosphere, 86(1), 36-40.

Raftery, T.D., Volz, D.C. (2015). Abamectin induces rapid and reversible hypoactivity within early zebra fish embryos. Neurotoxicology and Teratology, 49,10-18.

Salar-Almoli, J., Ali- Esfahani, T. (2015). Determination of hazardous substances in food basket eggs in Tahran, Iran: A preliminary study. Veterinary Research Forum, 6(2), 9-155.

Sardar, K., Zafer, K., Khalid, U., Sattar, N., Mustabshira, Z., Perveen, Sh. (2020). Effect of abamectin on development of chick embryo. Pure and Applied Biology, 9(2), 1266-1278.

Sharma, D., Sangha, G. K. (2014). Triazophos induced oxidative stress and histomorphological changes in liver and kidney of female albino rats. Pesticide Biochemistry and Physiology, 110, 71-80.

Singh, S.K., Tripathi, P.K., Yadav, R.P. (2004). Toxicity of malathion and carbaryl pesticides: effect on some biochemical profiles of the freshwater fish Calisa Fasciatus. Bull Archives of Environmental Contamination and Toxicology, 72(3), 592-599.

Srivastava, P.K., Singh, V.P., Singh, A., Singh, S., Prasad, S.M., Tripathi, D.K., Chauhan, D.K. (2020). Pesticides in Crop Production, Wiley Online Library: Hoboken, NJ, USA, 2020.

Stern, C.D. (2018). The chick model system: A distinguished past and a great future. International Journal of Developmental Biology, 62, 1-4.

Takahashi, Y., Matsumoto, A., Seino, A., Ueno, J., Iwai, Y., Omura, S. (2002). Streptomyces avermectinius sp. nov., an avermectin- producing strain. International Journal of Systematic and Evolutionary, 52, 21632168.

Teral, K., Dalmizrak, O., Hoti, Q., Ozer, N. (2018). Evaluation of the inhibitory effect of abamectin on mammalian butyrylcholinesterase: Enzyme kinetic and molecular docking studies. Journal of Environmental Science and Health, Part B, 53(11), 713-718.

Thiripurasundari, M., Sathya, K., Uma, A., Srinivasan, M.R., Rajasekar, P. (2014). A comparative study on the toxicity of ivermectin in Zebra fish and Calta fish models. Indo American Journal of Pharmaceuticl Research, 4(9), 3683-3688.

Uggini, G.K., Patel, P.V., Balakrishnan, S. (2012). Embryotoxic and teratogenic effects of pesticides on chick embryo, a comparative study using two commercial formulation. Environmental Toxicology, 27, 166-174.

Wilson, B.W., Arrieta, D.E., Henderson, J.D. (2005). Monitoring cholinesterase to detect pesticide exposure. Chemico-Biological Interactions, 2005, 157(158), 253-256.

Xu, Z., Liu, Y., Wei, P., Feng, K., Niu, J., Shen, G., Xu, Q., Wang, J., Smagghe, G.J., He, L. and Lu, W. (2017). High Gama- aminobutyric acid contents involved in abamectin resistance and predation, an interesting phenomenon in spider mites. Frontiers in Physiology, 8 , 216.

Yoon, Y.J., Kim, E.S., Hwang, Y.S., Choi, C.Y. (2004). Avermectin: Biochemical and molecular basis of its biosynthesis and regulation. Applied Microbiology and Biotechnology, 63(6), 626-634. 